\title{
ÚJ DIAGNOSZTIKAI MÓDSZEREK A RITKA BETEGSÉGEK FELISMERÉSÉBEN
}

\section{MODERN DIAGNOSTIC TECHNIQUES FOR DIAGNOSIS OF RARE DISEASES}

\author{
Haltrich Irén ${ }^{1}$, Fekete György² \\ 'PhD, biológus, tudományos fômunkatárs, citogenetikai laborvezető• haltrich.iren@med.semmelweis-univ.hu \\ egyetemi tanár, Semmelweis Egyetem Általános Orvostudományi Kar Il. sz. Gyermekgyógyászati Klinika, Budapest
}

\begin{abstract}
ÖSSZEFOGLALÁS
A Humán Genom Projekt befejezése és az elmúlt évtized genomalapú technológiáinak a fejlesztése lehetővé tette az ismeretlen eredetű, veleszületett rendellenességek/fejlődési elmaradások genetikai hátterének pontosabb és hatékonyabb feltárását. Közleményünkben a nem tisztázott kóreredetű (idiopátiás) fejlődési rendellenességgel és/vagy értelmi elmaradással született betegek genetikai diagnózisára alkalmazható korszerú és konvencionális citogenetikai metodikákat, valamint használatuk észszerű algoritmusait foglaljuk össze. Az array komparatív genomiális hibridizáció (a-CGH) a nemzetközi gyakorlatban elterjedt, első vonalbeli citogenetikai vizsgálat, mely kópiaszám-változások (CNV) (deléciók, duplikációk) és kópiaszám-semleges heterozigótaság-vesztés (LOH) detektálására alkalmas nagy felbontóképességű (50Kb) vizsgálat. A fluoreszcens in situ hibridizáció (FISH) fluorokrómmal jelzett DNS-próbákkal rekurrens törésponttal jellemezhető mikrodeléciós és mikroduplikációs szindrómák, valamint alacsony fokú mozaicizmusok azonosítására alkalmas vizsgálat. A standard metafázis-citogenetika technikai korlátai ellenére (5Mb, alacsony felbontás, osztódó sejtek) továbbra is értékes eszköz a kiegyensúlyozott kromoszóma-átrendeződések és a számbeli rendellenességek kimutatására.
\end{abstract}

\section{ABSTRACT}

The completion of the Human Genome Project and development of genome-based technologies over the past decade has enabled the recognition of chromosomal defects in higher proportion of patients with unexplained developmental delays. This review suggests a rational diagnostic algorithm for the targeted use of conventional and modern cytogenetic methods in patients with idiopathic developmental delay/intellectual disability. Array comparative genomic hybridization (a-CGH) has become the first-line investigation due to its higher resolution power $(50 \mathrm{~Kb})$ for unbalanced lesions and for the detection of copy-neutral loss of heterozigosity. Fluorescent in situ hybridization (FISH) analysis uses labelled DNA probes to identify submicroscopic deletions and duplications with recurrent breakpoints and low level mosaicism. However standard metaphase cytogenetics has technical limitations (5 Mb, low resolution, need of dividing cells) it remains a valuable tool for detection of balanced chromosomal rearrangements and numerical abnormalities. 
Kulcsszavak: fluoreszcens in situ hibridizáció (FISH), array komparatív genomiális hibridizáció (a-CGH), kópiaszám-változás (CNV), mikrodeléció, citogenetika

Keywords: fluorescence in situ hybridization (FISH), array-comparative genomic hybridization (a-CGH), copy number variation (CNV), microdeletion, cytogenetics

Az 1990-es évek elején elindult Humán Genom Projekt, az emberi DNS szekvenálási programja a teljes genom megfejtését tüzte ki célul. A tudósok és a mindennapi emberek egyaránt óriási lehetőséget láttak a program megvalósulásában: egyrészt abban bíztak, hogy rövid időn belül fény derül valamennyi mendeli öröklődésü betegség genetikai okára, megtalálják a szív- és érrendszeri betegségek, a stroke, a rák, a demencia, az asztma kialakulásáért felelős géneket, és a genom ismeretére alapozott gyógyszerkutatások lehetővé teszik új gyógyszer-támadáspontok felfedezését és a betegségek hatékonyabb gyógyítását. A program a vártnál korábban fejeződött be, óriási megfejtendő adathalmazzal látta el a kutatókat, és a szó szoros értelmében forradalmasította az orvosi diagnosztikai módszereket.

\section{KLASSZIKUS CITOGENETIKA - TÖRTÉNETI ÁTTEKINTÉS}

A ritka betegségek genetikai diagnózisa jóval korábban, a múlt század derekán indult, amikor Jo Hin Tjio és Albert Levan megállapította, hogy az emberi kromoszómakészlet 46 kromoszómából áll. A sejttenyészet gyors fejlődése lehetővé tette az emberi kromoszómák rutinszerủ preparálását, és hamarosan megszületett a kromoszómákkal, azok öröklődésben és betegségekben betöltött szerepével foglalkozó új tudományág, a citogenetika. Az új tudományág hőskora létrejöttének első évtizedére esik: tíz év leforgása alatt azonosították az összes autoszomális kromoszóma számbeli elváltozásával járó szindrómát. Jérôme Lejeune felfedezte, hogy a Down-kórt a 21-es kromoszóma többlete, triszómiája okozza, a 13-as és a 18-as triszómiát felfedezőjükről Patau-, illetve Edwards-szindrómának nevezték el. A nemi kromoszómák többletével vagy hiányával kapcsolatosan újabb kórképeket írtak le: Patricia Jacobs és John Strong az XXY nemi kromoszómaképlettel társuló Klinefelter-szindrómát, Charles Edmund Ford és munkatársai a Turner-szindrómának megfelelő X monoszómiát írta le. Hamarosan fény derült arra is, hogy a spontán abortuszok nagy részét a magzat számbeli vagy szerkezeti kromoszóma-rendellenessége okozza. A fenti számbeli kromoszóma-elváltozással járó kórképek diagnózisa a mai napig - a hazai és a nemzetközi laboratóriumokban - kariotípus meghatározással történik (Haltrich, 2018). A szerkezeti rendellenességek azonosításához szükséges módszertani áttörés Torbjörn Caspersson ne- 
véhez kötődik, akinek elsőként sikerült úgy megfestenie a kromoszómákat, hogy mindegyiknek egyedi ,arca” legyen. A kromoszómák különböző sóoldatokkal történő kezelésével, az úgynevezett „sávozással” sokkal több részlet volt követhető a kromoszómákon, és a szerkezeti elváltozások azonosítása is lehetségessé vált. Elsőként Lejeune azonosította az 5-ös kromoszóma rövid kar terminális delécióját, melyet a macskanyávogáshoz hasonló sírás miatt „cri du chat” szindrómának neveztek el. Később más kromoszómákon is azonosítottak különböző méretü vesztéseket, visszatérő deléciókat, melyek közül a leggyakoribb a Wolf-szindróma (4-es kromoszóma rövid kar deléció) és a De Grouchy-szindróma (18-as kromoszóma parciális deléció). Szép lassan feltérképezték a kromoszómák szerkezeti rendellenességeit, melyek közül legismertebbek a transzlokációk, inverziók, deléciók és duplikációk. Általában elmondható, hogy a kiegyensúlyozatlan elváltozások okoznak betegségeket. Mivel az átrendeződések egyénenként különböző kromoszómarégiókat érintenek, mindegyik elváltozás különböző fenotípust eredményez, és ezért ritka betegségnek tekinthető.

Az 1960-as évek végén a magzatvízvétellel (amniocentézissel) nyert magzati sejtek tenyésztése megnyitotta a születés előtti, prenatális citogenetika fejezetét, mely lehetővé tette a magzat kromoszóma-betegségeinek szürését. Azonban a fenti felfedezésekkel nagyjából be is fejeződnek a klasszikus citogenetika ritka betegségekkel kapcsolatos diagnosztikus lehetőségei, mivel a sávos kromoszómákon is csak a durvább, általánosan 3 megabázisnál $(\mathrm{Mb})$ nagyobb eltérések azonosíthatók (Haltrich, 2013).

A humán citogenetika fejlődésének újabb lendületet a krónikus mieloid leukémiás betegek csontvelői mintájában felfedezett miniatür kromoszóma adott, melyet felfedezésének helyszínéről Philadelphia-kromoszómának neveztek el. Janet Rowley tizenhárom évvel később bebizonyította, hogy a Philadelphia-kromoszóma a 9-es és a 22-es kromoszómák közti reciprok transzlokáció eredménye, melynek során az említett kromoszómák egy-egy szakasza kölcsönösen kicserélődik. Később azonosították a töréspontokban található géneket: a 9-es kromoszómán található ABL 1- (Proto-Oncogene 1, Non-Receptor Tyrosine Kinase) és a 22-es kromoszómán található BCR- (Breakpoint Cluster Region) gént, melyek a transzlokáció során fuzionálnak, és kóros aktivitású tirozin-kináz-fehérje termelődését eredményezik, mely kiváltja a sejtek leukémiás transzformációját (Chandra et al., 2011).

Ez a felfedezés mérföldkő a korszerü diagnosztikai módszerek fejlődésében, mivel a mikroszkóppal történő értékelésről a molekuláris színtủ kutatások felé irányította a szakemberek érdeklődését, és a génszintủ elváltozások detektálására alkalmas metodika kidolgozására sarkallta őket. Az új molekuláris citogenetikai módszerek alapja a fluoreszcens in situ hibridizáció (FISH), mely lehetővé teszi a kromoszómák és a gének közti átjárhatóságot, és láthatóvá teszi, molekuláris szintre „nagyítja” a kromoszóma-rendellenességeket. 


\section{FLUORESZCENS IN SITU HIBRIDIZÁCIÓ (FISH)}

Az in situ hibridizációt először radioaktív jelölésű genomiális DNS-darabokkal végezték el a 70-es évek tájékán, azonban a klinikai gyakorlati alkalmazása csak a 90-es években terjedt el, miután Daniel Pinkelnek és munkatársainak sikerült egy sokkal könnyebben kivitelezhetö, fluorokróm-alapú DNS-festést alkalmazniuk.

A FISH-vizsgálat során a beteg kettős szálú DNS-ét magas hőmérsékleten szétválasztjuk, denaturáljuk, majd ismert szekvenciájú, fluorokrómmal „festett” egyszálú DNS-próbákhoz hibridizáljuk. A próba a DNS-komplementaritás alapján bekötődik a targethez, és ezáltal a genom kisebb szakaszai fluoreszcens mikroszkóp segítségével jeleníthetők meg (1. ábra).

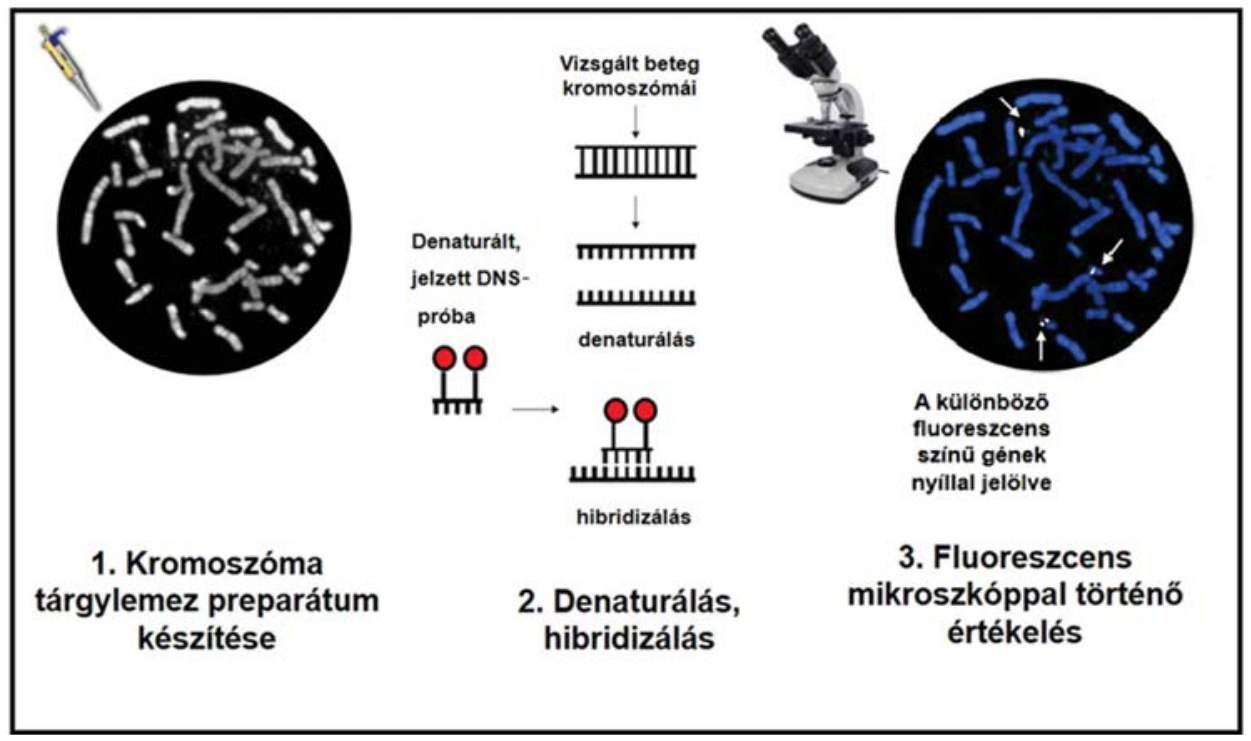

1. ábra. A fluoreszcens in situ hibridizáció technikai lépéseinek sematikus ábrázolása. HI saját készítésủ ábrája és mikroszkópi felvétele

A módszer előnye, hogy a fénymikroszkóppal nem követhető, kilóbázis nagyságrendü „rejtett” elváltozásokat képes detektálni: megállapítható a keresett kromoszómarégió, gén (szakasz) jelenléte vagy hiánya, kópiaszáma, kromoszomális helye (Tönnies, 2002). FISH-vizsgálattal csak akkor tudjuk diagnosztizálni a ritka betegségeket, ha rendelkezünk klinikai genetikai ismeretekkel, és ismerjük a beteg részletes tünettanát. A diagnózis kiindulópontja mindig a fenotípus (phenotype-first), ennek a feltérképezése segít körvonalazni a lehetséges genotípust, melyet a célzott FISH-vizsgálattal tudunk igazolni. 
A FISH-vizsgálat eredményessége a megfelelő FISH-próbák kiválasztásától is függ. Bizonyos kromoszómák számának megállapításához a centromérák közelében elhelyezkedő, különböző $\alpha$-szatellita régiókat tartalmazó, az adott kromoszómára specifikus próbák alkalmasak, melyeket „kromoszóma-számláló” próbáknak (chromosome enumaration probe, CEP) vagy centroméraspecifikus próbáknak nevezünk. E próbák előnye, hogy nem igényelnek metafázis kromoszómákat, különböző szövetekből (vizelet laphám vagy szájnyálkahártya) származó interfázis sejtmagokon is kivitelezhetők. A centroméra próbákkal biztonsággal diagnosztizálhatók a rejtett és a szöveti mozaicizmusok, mivel a vizsgált kromoszóma száma akár több száz sejtben is ellenőrizhető. Ilyen rejtett mozaicizmus fordulhat elő például az olyan típusú Turner-szindrómában, ahol a második nemi kromoszóma csak a sejtek egy részéből hiányzik. Ha a második nemi kromoszóma egy szerkezetileg hibás Y kromoszóma, az osztódások során a sejtek nagy részéből általában elvész. A klinikai gyakorlatban különös jelentősége van a Turner-szindrómában előforduló Y kromoszóma mozaicizmusoknak, mivel a gonádok rosszindulatú daganatos elváltozásának kockázata ezekben az esetekben az átlagosnál jóval magasabb ( 25\%), és emiatt a beteg szoros orvosi felügyeletet igényel (2. ábra).

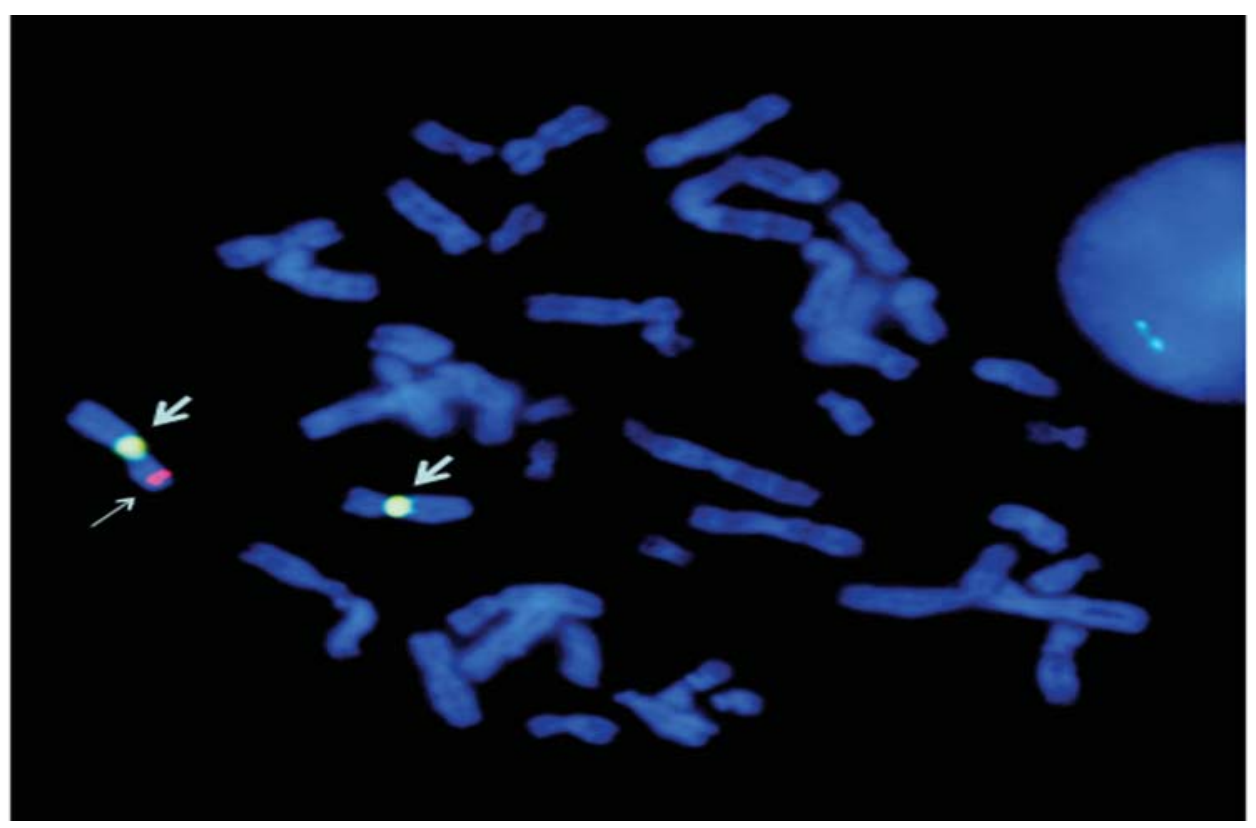

2. ábra. A férfi nemet determináló Y-régió-gén (SRY) X kromoszómára történő transzlokációjának FISH mintázata.

A vastagabb nyíl a női nemnek megfelelő két X kromoszómát azonosító centromérát, a vékonyabb nyíl az SRY-gént mutatja az egyik X kromoszómán.

HI saját diagnosztikai anyagának mikroszkópi felvétele 
A FISH legkiterjedtebb alkalmazási területe a ritka betegségek területén a mikrodeléciós szindrómák diagnózisa. A mikrodeléciók kialakulására a genomban szétszórtan található instabil kromoszóma-régiók hajlamosítanak. A mikrodeléciós szindrómákkal összefüggő instabil régiók közül legismertebbek az alacsony kópiaszámú ismétlődések (low-copy repeat, LCR), melyek a mikrodeléciós szindrómák töréspontjait határolják. Az ivarsejtek keletkezésével kapcsolatos meiózis során az egymáshoz közeli LCR-régiók szekvenciaazonosságának köszönhetöen hibás párba rendeződés, úgynevezett „nem allélikus homológ rekombináció” jöhet létre, amelynek következtében az LCR-régiók közti szakaszok kieshetnek vagy megduplázódhatnak. Mivel a töréspontok mindig az LCR-régiókra lokalizálódnak, a mikrodeléciós szindrómák ismert, úgynevezett „rekurrens” törésponttal rendelkeznek. A mikrodeléciós szindrómák diagnózisára éppen ezért könnyen tervezhetők az úgynevezett génspecifikus vagy lókuszspecifikus FISH-próbák, melyekben a deléciós/duplikációs kritikus régiót általában piros fluorokrómmal jelölik, és tartalmaznak még egy zöld fluorokrómmal jelölt kontrollrégiót, amellyel ellenőrizhető a kromoszomális lokalizáció, és validálható a kritikus régióval kapcsolatos eredmény is. Valamennyi rekurrens törésponttal jellemezhető mikrodeléciós és mikroduplikációs szindróma (Williams-Beuren-, DiGeorge-, Smith-Magenis-, Prader-Willi-, Angelman-, cat-eye-, Charcot-MarieTooth-szindróma stb.) FISH-vizsgálattal biztonsággal diagnosztizálható (Shaffer et al., 2007). Ez a társadalombiztosítás által támogatott vizsgálat szinte valamenynyi hazai citogenetikai laboratóriumban elérhető.

Bizonyos szindrómákban jelentősége van a szülöi eredetnek is: ugyanannak a régiónak a kiesése más betegséget okoz a szülői eredet függvényében. Elöfordulhat az is, hogy mindkét homológ kromoszómán jelen van a mikrodeléciós szindróma kritikus régiója, azonban mindkét kópia csak az egyik szülőtől származik. Ezt a jelenséget egyszülős vagy uniparentális diszómiának (UPD) nevezzük. Ilyen szülői hatástól függő például a 15-ös kromoszóma centroméra alatti régiójának (15q11) az elvesztése, amely az apai allélvesztés esetében a súlyos súlytöbblettel és értelmi elmaradással járó Prader-Willi-szindrómát eredményezi, akkor is, ha nincs deléció, de mindkét allél az anyától származik. Ennek a fordítottja az Angelman-szindróma, ahol csak az apai allél van jelen egy vagy két kópiában. Ezekben az esetekben metilációspecifikus multiplex ligációfüggő próbaamplifikációs (MLPA) vizsgálat elvégzése szükséges, mely különbséget tud tenni a szülöi allélok között (Ács et al., 2018).

A FISH másik gyakori klinikai alkalmazása a génekben gazdag szubtelomerikus régiók vizsgálata (De Vries et al., 2003). Ezek a régiók a meiózis során gyakran átrendeződnek, és különböző súlyosságú értelmi elmaradást és/vagy tanulási nehézséget okoznak. Valamely kromoszóma szubtelomerikus deléciója az értelmi elmaradással született gyermekek 5\%-ára jellemző. Ezekben az esetekben az értelmi elmaradáshoz általában valamilyen fejlődésbeli elmaradás és/vagy disz- 
morfiás jelleg is kapcsolódik (Ravnan et al., 2006). Valamennyi kromoszóma szubtelomerikus régiójára van kereskedelmi forgalomban elérhető próba, azonban a vizsgálat elég költség- és munkaigényes.

Amennyiben a hagyományos citogenetikai vizsgálat több kromoszómát érintő, úgynevezett komplex szerkezeti elváltozást azonosít, a teljes kromoszómafestő próbák (whole chromosome painting probe, WCP) kombinációit használhatjuk, azonban az optimális megoldás a sokkal költségesebb multicolor-FISH-technika, mely öt különbözö fluorokróm keverékét felhasználva minden egyes kromoszómát más színben jelenít meg (Tönnies, 2002).

\section{ARRAY KOMPARATÍV GENOMIÁLIS HIBRIDIZÁCIÓ (ARRAY-CGH)}

A ritka citogenetikai kórképek legkorszerübb diagnosztikus módszere a nagy felbontóképességủ array komparatív genomiális hibridizáció (array-CGH). Óriási előnye, hogy alkalmas sporadikus töréspontú, ismeretlen, kisméretü kópiaszámváltozások (CNV) (deléciók, duplikációk) detektálására. A vizsgálat a beteg DNS-mintájából és egy egészséges kontrollmintából, az úgynevezett referencia DNS-ből történik.

Az array- $\mathrm{CGH}$, akárcsak a kariotipizálás, az egész genomra vonatkozóan ad információt, azonban felbontóképessége lényegesen nagyobb, akár tízezerszeres is lehet. A kereskedelemben különböző felbontóképességü array kitek vannak forgalomban, attól függően, hogy a próbák milyen távolságra vannak egymástól. A legelterjedtebb, kereskedelmi forgalomban lévő nagyfelbontású array-k (500 K probes) általában $50 \mathrm{~Kb}$ nagyságú eltérést tudnak detektálni, a kisebb felbontásúak (180 K probes) pedig $150 \mathrm{~Kb}$ körüli kópiaszám-változást tudnak érzékelni. Egyéni kérésre készített kitek segítségével a genom egy része, például egyetlen kromoszóma, sokkal részletesebben is vizsgálható. Ha a próbák számát célzottan növeljük, akár $5 \mathrm{~Kb}$ nagyságú eltérést is lehet azonosítani. Az utóbbi években bizonyos betegségekkel, szindrómákkal kapcsolatos gének vizsgálatára dolgoztak ki speciális array kiteket.

Az array-CGH-kit egy tárgylemez méretü lapka, amelyhez több százezer rövid, 50-80 nukleotidból álló egyszálú DNS-molekulát, oligonukleotidot rögzítenek. A beteg DNS mintáját (vörös-Cy5) és az egészséges kontrolloktól származó referencia DNS-t (zöld-Cy3) különböző színü flurokrómmal jelölik, egyenlő menynyiségben összekeverik, majd az array-lapkára cseppentik. A beteg és kontroll mintakeverék kétszálú DNS-t elválasztják, denaturálják, majd a szilárd felületen található oligonukleotid próbákhoz hibridizálják. Ezt követően egymás után, különböző színủ lézerrel gerjesztve, szkennerrel beolvassák a képet, majd az adatokat bioinformatikai programok segítségével értelmezik. A hiány és a többlet a beteg minta és a referencia DNS fluoreszcens jelintenzitásának detektálásán alapul. A normális DNS-szakaszokon a két szín egyenlő erősségü, így sárga jelet ka- 
punk; duplikáció esetén a beteg vörös színủ DNS-éből hibridizálódik több, deléció esetén a kontroll DNS zöld színe van túlsúlyban (3. ábra). Az array kitek egy részébe egypontos-nukleotid-polimorfizmussal kapcsolatos SNP-markereket is beépítenek. A szkenner az SNP-markerek alapján különbséget tud tenni az anyai és az apai allélok között. Az ilyen típusú kitek alkalmasak kópiaszám-semleges heterozigóta állapotvesztések (LOH), uniparentális diszómiák (UPD) feltárására is (Ellison et al., 2012; Pikó-Karcagi, 2014).

\section{DNS-izolálás és -jelölés \\ Vizsgált DNS \\ Cy5 \\ Referencia DNS

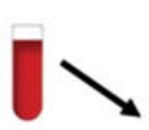 \\ Су3

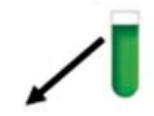

2. Hibridizálás

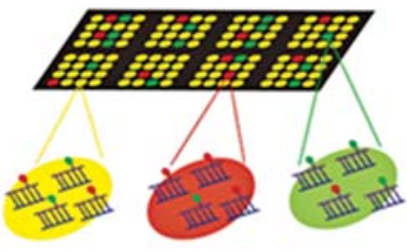

\section{Szkennelés}

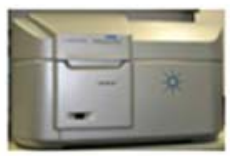

\section{Bioinformatikai értékelés}

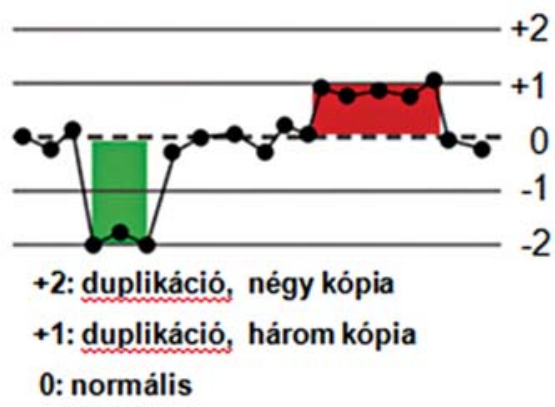

-1: heterozigóta deléció

-2: homozigóta deléció

3. ábra. Az array komparatív genomiális hibridizációval történő vizsgálat folyamatának sematikus ábrázolása.

A szerzők saját készítésű ábrája

Az array kitek próbatávolsága általában arányos a gének sủrüségével, a centroméra körüli génszegény régiók, szegmentális duplikációk általában nincsenek lefedve, ezért ezek kópiaszám-változásairól, valamint a mitochondriális DNS-ről nem kapunk információt. Az array-CGH nem alkalmas kiegyensúlyozott elváltozások (reciprok transzlokációk, inverziók), alacsony fokú (15\%) mozaicizmusok, valamint mutációk detektálására sem. 
Az array vizsgálatnál a diagnózis kiindulópontja a genotípus (genotype first), a talált genotípus kell, hogy elvezessen a fenotípus megértéséhez. Könnyü megtalálni a diagnózist, ha az azonosított CNV megtalálható az adatbázisokban, és a társuló klinikai jellemzők is megegyeznek. Természetesen sok olyan elváltozást is azonosíthat az array vizsgálat, melynek klinikai jelentőségére nincs adat, patogenitása nem egyértelmü. Az ilyen eredmény „,bizonytalan klinikai jelentőségü variánsként" (variant of uncertain clinical significance, VOUS) kerül be az adatbázisba. A kópiaszám-változások egy részéről az adatbázisokban azonban nincs semmilyen információ, mivel azt korábban nem azonosították, vagy nem regisztrálták. Ebben az esetben szükséges az érintett régióban, illetve a szomszédságában található gének feltérképezése, funkciójuk és expressziójuk helyének és idejének tanulmányozása (De Leeuw et al., 2012).

Amennyiben a fenotípus eltérő, további vizsgálatok elvégzése (például a teljes exom szekvenálása, a lehetséges mutációk PCR vizsgálata) vezethet el a betegség patomechanizmusának a felfedéséhez.

Az array-CGH a nemzetközi gyakorlatban elterjedt, elsődleges citogenetikai vizsgálat ismeretlen eredetű fejlődési rendellenességek és értelmi elmaradások esetében. A hazai rutin genetikai diagnosztikába való bevezetése, a társadalombiztosítás által történő finanszírozásának megoldása rendkívül sürgető.

\section{IRODALOM}

Ács O. D. - Péterfia B. - Hollósi, P. et al. (2018): Elsődleges genetikai vizsgálat Prader-Willi-szindróma igazolására. Orvosi Hetilap, 159, 2, 64-69. DOI: 10.1556/650.2018.30918, http:// real.mtak.hu/72747/

Chandra, H. S. - Heisterkamp, N. C. - Hungerford, A. et al. (2011): Philadelphia Chromosome Symposium: Commemoration of the $50^{\text {th }}$ Anniversary of the Discovery of the Ph Chromosome. Cancer Genetics, 204, 4, 171-179. DOI: 10.1016/j.cancergen.2011.03.002, https://www.ncbi. nlm.nih.gov/pmc/articles/PMC3092778/

Ellison, J. W. - Ravnan, J. B. - Rosenfeld, J. A. et al. (2012): Clinical Utility of Chromosomal Microarray Analysis. Pediatrics, 130, 5:e1085-1095. DOI: 10.1542/peds.2012-0568

Haltrich I. (2013): Hagyományos és modern technikák a citogenetikai diagnózis szolgálatában. Gyermekgyógyászat, 64, 59.

Haltrich I. (2018): A veleszületett rendellenességek korszerü diagnosztikai vizsgálatai. Gyermekgyógyászati Továbbképzö Szemle, 23, 2, 78-82.

De Leeuw, N. - Dijkhuizen, T. - Jayne Y. et al. (2012): Diagnostic Interpretation of Array Data Using Public Databases and Internet Source. Human Mutation, 33, 6, 930-940. DOI: 10.1002/ humu.22049, https://www.ncbi.nlm.nih.gov/pmc/articles/PMC5027376/

Pikó H. - Karcagi V. (2014): Komparatív genomiális hibridizálás (CGH). Gyermekgyógyászat, $65,16-18$.

Ravnan, J. B. - Tepperberg, J. H. - Papenhausen, P. et al. (2006): Subtelomere FISH Analysis of 11688 Cases: An Evaluation of the Frequency and Pattern of Subtelomere Rearrangements in Individuals with Developmental Disabilities. Journal of Medical Genetics, 43, 
6, 478-489. DOI: 10.1136/jmg.2005.036350, https:/www.ncbi.nlm.nih.gov/pmc/articles/ PMC2564531/

Shaffer, L. G. - Bejjani, B. A. - Torchia, B. et al. (2007): The Identification of Microdeletion Syndromes and Other Chromosome Abnormalities: Cytogenetic Methods of the Past, New Technologies for the Future. American Journal Of Medical Genetics. Part C. Seminars in Medical Genetics, 145C, 335-345. DOI:10.1002/ajmg.c.30152, https://bit.ly/2W9YTPX

Tönnies, H. (2002): Modern Molecular Cytogenetic Techniques in Genetic Diagnostics. Trends in Molecular Medicine, 8, 6, 246-250. DOI: 10.1016/S1471-4914(02)02335-3, https://www.researchgate.net/publication/11306289_Modern_molecular_cytogenetic_techniques_in_genetic_diagnostics

De Vries, B. B. - Winter, R. - Schinzel, A. et al. (2003): Telomeres: A Diagnosis at the End of the Chromosomes. Journal of Medical Genetics, 40, 6, 385-398. https://jmg.bmj.com/content $/ 40 / 6 / 385$.long 